\title{
Upregulation of Forebrain NMDA NR2B Receptors Contributes to Behavioral Sensitization after Inflammation
}

\author{
Long-Jun Wu, ${ }^{1}$ Hiroki Toyoda, ${ }^{1}$ Ming-Gao Zhao, ${ }^{1}$ Yong-Seok Lee, ${ }^{6}$ Jianrong Tang, ${ }^{1}$ Shanelle W. Ko, ${ }^{1}$ Yong Heng Jia, ${ }^{1}$ \\ Fanny W. F. Shum, ${ }^{1}$ Celina V. Zerbinatti, ${ }^{2}$ Guojun Bu, ${ }^{2}$ Feng Wei, ${ }^{1}$ Tian-Le Xu, ${ }^{4}$ Louis J. Muglia, ${ }^{2}$ Zhou-Feng Chen, ${ }^{3}$ \\ Yves P. Auberson, ${ }^{5}$ Bong-Kiun Kaang, ${ }^{6}$ and Min Zhuo ${ }^{1}$ \\ ${ }^{1}$ Department of Physiology, Faculty of Medicine, University of Toronto Centre for the Study of Pain, Toronto, Ontario, Canada M5S 1A8, Departments of \\ ${ }^{2}$ Pediatrics, Anesthesiology, Psychiatry, and Molecular Biology and ${ }^{3}$ Pharmacology, Washington University in St. Louis, St. Louis, Missouri 63110, \\ ${ }^{4}$ Institute of Neuroscience, Chinese Academy of Sciences, Shanghai 200031, China, ${ }^{5}$ Novartis Institutes of Biomedical Research, Novartis Pharma AG,

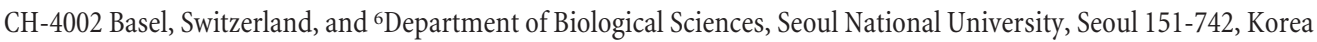

Transgenic overexpression of NMDA NR2B receptors in forebrain regions increased behavioral responses to persistent inflammatory pain. However, it is not known whether inflammation leads to the upregulation of NR2B receptors in these regions. Here, we show that peripheral inflammation increased the expression of NMDA NR2B receptors and NR2B receptor-mediated synaptic currents in the anterior cingulate cortex (ACC). In freely moving mice, the increase in NR2B receptors after inflammation contributed to enhanced NMDA receptor-mediated responses in the ACC. Inhibition of NR2B receptors in the ACC selectively reduced behavioral sensitization related to inflammation. Our results demonstrate that the upregulation of NR2B receptors in the ACC contributes to behavioral sensitization caused by inflammation.

Key words: NMDA receptors; NR2B; anterior cingulate cortex; inflammation; pain; hyperalgesia

\section{Introduction}

Functional NMDA receptors contain heteromeric combinations of the NR1 subunit plus one or more of NR2A-D (Nakanishi et al., 1992; Hollmann et al., 1994), of which the NR2A and NR2B subunits are the major NR2 subtypes found in forebrain structures (Monyer et al., 1994). Recent studies show that NMDA receptors undergo plastic changes in physiological or pathological conditions. For example, NMDA receptors are composed almost exclusively of NR1 and NR2B subunits at birth, gradually incorporating more NR2A subunits during postnatal development in most brain areas (Monyer et al., 1994; Sheng et al., 1994). NR2B receptors are downregulated during maintenance of fear memory or phosphorylated in response to taste memory (Rosenblum et al., 1997; Zinebi et al., 2003). Furthermore, in the visual cortex, experience-dependent plasticity is reported to cause changes in the NR2A:NR2B ratio, favoring the expression of NR2A (Philpot et al., 2001a,b; Sawtell et al., 2003; Tongiorgi et al., 2003). Olfactory learning has also been shown to affect the NR2A: NR2B ratio (Quinlan et al., 2004).

Received April 27, 2005; revised 0ct. 18, 2005; accepted 0ct. 18, 2005.

This work was supported by grants from the EJLB-Canadian Institutes of Health Research Michael Smith Chair in Neurosciences and Mental Health, the Canada Research Chair, and the Canadian Institute for Health Research and National Institutes of Health-National Institute of Neurological Disorders and Stroke Grant NS42722 (M.Z.). M.-G.Z. is supported by the Fragile X Foundation of Canada. B.-K.K. was supported in part by National Research Laboratory, Brain Research Center-Frontier Program, Korea.

Correspondence should be addressed to Dr. Min Zhuo, Department of Physiology, University of Toronto, Faculty of Medicine, Medical Science Building, Room 3342, 1 King's College Circle, Toronto, Ontario, Canada M5S 1A8. E-mail:min.zhuo@utoronto.ca.

DOI:10.1523/JNEUROSCI.1678-05.2005

Copyright $\odot 2005$ Society for Neuroscience $\quad$ 0270-6474/05/2511107-10\$15.00/0
Based on our previous work, we hypothesize that NMDA receptor function undergoes upregulation in the anterior cingulate cortex (ACC). This increase in NMDA receptors in ACC neurons thereby contributes to chronic pain by enhancing the neuronal activity within (or between) the hemispheres of the ACC. Our working hypothesis is supported by the following observations: (1) NMDA receptors, including NR1, NR2A, and NR2B, are highly expressed in forebrain areas (Monyer et al., 1994; Wei et al., 2001); (2) systemic application of NMDA receptor antagonists inhibited inflammation-related persistent pain in animals and chronic pain in humans, with a recent note that NR2B receptor antagonists may have less side effects (Boyce et al., 1999; Zhuo, 2002); (3) genetic deletion of postsynaptic density-93 significantly reduced NMDA receptor-mediated currents in spinal dorsal horn neurons/ACC neurons and persistent pain (Tao et al., 2003); (4) local microinjection of the NMDA receptor antagonist AP-5 into the ACC blocked inflammation-related allodynia (Wei et al., 2002); and (5) in transgenic mice with forebraintargeted NR2B overexpression (Bliss, 1999; Tang et al., 1999), inflammation-related pain was selectively enhanced (Wei et al., 2001).

One critical question related to our hypothesis is whether NMDA NR2B receptors indeed undergo long-term upregulation in the ACC under physiological or pathological conditions. Here, we show that the NR2B receptor undergoes prolonged upregulation in ACC neurons after tissue inflammation, and NMDA receptor-mediated responses were enhanced in both in vitro brain slices and freely moving animals. Inhibition of NR2B receptors by administering selective NR2B receptor antagonists locally into the ACC or systemically, inhibited inflammation-related al- 
lodynia. Our results suggest a new role for NMDA receptors in long-term behavioral sensitization to peripheral injury.

\section{Materials and Methods}

Animals. Adult (8-12 weeks of age) C57BL/6J mice were housed individually and maintained on a $12 \mathrm{~h}$ light/dark cycle. Food and water were provided ad libitum. The Animal Studies Committee at Washington University and University of Toronto approved the experimental protocols. Experiments related to the treatment [i.e., complete Freund's adjuvant (CFA) vs saline injection] were performed blind.

Whole-cell patch-clamp recordings in adult slices. Adult male mice were anesthetized with 1-2\% halothane. Transverse slices containing ACC, ventrobasal thalamus, or somatosensory cortex $(300 \mu \mathrm{m})$ were prepared using standard methods (Wei and Zhuo, 2001). Slices were transferred to a room temperature submerged recovery chamber with oxygenated (95\% $\mathrm{O}_{2}$ and $5 \% \mathrm{CO}_{2}$ ) solution containing the following (in $\mathrm{mm}$ ): 124 $\mathrm{NaCl}, 25 \mathrm{NaHCO}_{3}, 4.4 \mathrm{KCl}, 1 \mathrm{KH}_{2} \mathrm{PO}_{4}, 2 \mathrm{CaCl}_{2}, 2 \mathrm{MgSO}_{4}$, and 10 glucose. After $1 \mathrm{~h}$ of recovery, slices were placed in a recording chamber on the stage of an Axioskop 2FS microscope (Zeiss, Thornwood, NY) equipped with infrared DIC optics for visualized whole-cell patch-clamp recordings. Excitatory postsynaptic currents were recorded from layer II/III neurons in the ACC or somatosensory cortex or neurons in ventrobasal thalamus with an Axon 200B amplifier (Molecular Devices, Union City, CA), and local stimulations were delivered by a bipolar tungsten stimulating electrode. Recording electrodes $(2-5 \mathrm{M} \Omega$ ) contained a pipette solution composed of the following (in $\mathrm{mM}$ ): $120 \mathrm{~K}$-gluconate, 5 $\mathrm{NaCl}, 1 \mathrm{MgCl}_{2}, 0.5$ EGTA, 2 Mg-ATP, $0.1 \mathrm{Na}_{3}$ GTP, 10 HEPES, pH 7.2, 280-300 mOsm. To examine the voltage dependence of EPSCs, Csgluconate was used to replace the K-gluconate. Access resistance was 15-35 $\mathrm{M} \Omega$ and was monitored throughout the experiment. Data were discarded if access resistance changed $>10 \%$ during an experiment. The membrane potential was held at $-65 \mathrm{mV}$ throughout the experiment. When recording NMDA EPSCs, a holding potential of $-30 \mathrm{mV}$ was used as indicated. In some experiments, to compare the time constants of NR2A- and NR2B-mediated EPSCs, evoked EPSCs were recorded at -60 $\mathrm{mV}$ in $\mathrm{Mg}^{2+}$-free artificial CSF.

Confocal imaging. To determine the morphology of ACC neurons, patch pipettes were filled with $0.1 \%$ Lucifer yellow. The loaded cells were imaged using a confocal microscope (Olympus Fluoview IX70; Olympus Optical, Tokyo, Japan) after whole-cell recording. Composite images were obtained by stacking the optical sections into a two-dimensional image.

Western blot and immunoprecipitation. Brain regions were douncehomogenized (18 strokes) in 10 volumes of PBS containing $1 \mathrm{mM} \mathrm{Mg}^{2+}$, $0.5 \mathrm{~mm} \mathrm{Ca}^{2+}, 1 \%$ Triton X-100, $1 \mathrm{~mm}$ PMSF, and protease inhibitor mixture (Complete; Roche Diagnostics, Welwyn Garden City, UK) or in $10 \mathrm{~mm}$ Tris, $\mathrm{pH}$ 7.4, $320 \mathrm{~mm}$ sucrose, and 1\% SDS. Lysates were centrifuged at $14,000 \mathrm{rpm}, 4^{\circ} \mathrm{C}$ for $5 \mathrm{~min}$, and the supernatants were used for protein analysis and Western blotting. Equal amounts $(10-30 \mu \mathrm{g})$ of protein from tissue lysates were separated by SDS-PAGE and transferred to polyvinylidene difluoride membrane followed by blocking with $3 \%$ BSA and 3\% skim milk for $1 \mathrm{~h}$ at room temperature. Blots were probed with anti-NR2A (1:5000), anti-NR2B (1:3000; Chemicon, Temecula, CA), or anti-NR1 (1:3000; Upstate Biotechnology, Lake Placid, NY) polyclonal antibodies overnight at $4^{\circ} \mathrm{C}$. For actin blotting as a control, a monoclonal antibody from Sigma (St. Louis, MO; 1:5000) was used. The membranes were incubated with a horseradish peroxidase-conjugated goat anti-rabbit IgG (1:2500; Sigma) for $1 \mathrm{~h}$ at room temperature, and the bands were visualized by an ECL system (PerkinElmer, Wellesley, MA). Exposure time varied for each primary antibody to ensure that the signals were in the linear range. Signals were quantified using ImageJ software and then normalized to the saline-injected controls. For immunoprecipitation, the solubilized proteins were diluted 20 -fold with modified radioimmunoprecipitation assay buffer (50 mм Tris- $\mathrm{HCl}, \mathrm{pH} 7.4,1 \% \mathrm{NP}-40$, $0.25 \%$ Na-deoxycholate, $150 \mathrm{~mm} \mathrm{NaCl}, 1 \mathrm{~mm}$ EDTA, $1 \mathrm{~mm}$ PMSF) and incubated with $50 \mu \mathrm{l}$ of protein G-agarose precoupled with antiphosphotyrosine antibody (PY20; BD Biosciences, Franklin Lakes, NJ) for $3 \mathrm{~h}$ at $4^{\circ} \mathrm{C}$. The reaction mixtures were then washed three times and eluted by boiling in sample loading buffer and subjected to Western blot analysis as described above.

Electrophysiological recordings in freely moving mice. Mice were anesthetized with sodium pentobarbital ( $80 \mathrm{mg} / \mathrm{kg}$, i.p.) and implanted bilaterally with a tungsten electrode in the ACC $(0.62 \mathrm{~mm}$ anterior, $0.4 \mathrm{~mm}$ lateral, and $1.7 \mathrm{~mm}$ ventral to the bregma) under aseptic conditions. The tungsten wire extended $0.1-0.2 \mathrm{~mm}$ beyond the guide cannula that was used as a reference. For pharmacological tests, mice were implanted bilaterally with 24-gauge stainless steel cannulas into the ACC. Dental cement was used to keep the electrodes or cannulas in place. Mice were allowed to recover for 2 weeks before the experiments. Test responses were elicited by monophasic stimuli $(200 \mu \mathrm{s} ; 75-190 \mu \mathrm{A} ; 1 / 60 \mathrm{~s})$ at an intensity that evoked $40-50 \%$ of the maximal responses. At the end of the experiment, using standard histological methods, $30 \mu \mathrm{m}$ brain sections were stained with cresyl violet and examined by light microscopy for electrode placements or cannula penetrations.

Behavioral experiments. The tail-flick (TF) reflex was evoked by focused, radiant heat applied to the underside of the tail. The latency to reflexive removal of the tail away from the heat was measured by a photocell timer to the nearest $0.1 \mathrm{~s}$. In the hot-plate (HP) test, mice were placed on a thermally controlled metal plate. The time between the placement of the mouse on the plate and licking or lifting of a hindpaw was measured.

For inflammatory pain, complete Freund's adjuvant (50\% in saline, 10 $\mu \mathrm{l}$; Sigma) was injected into the dorsal surface of the left hindpaw. After 24 and $72 \mathrm{~h}$, animals were placed in individual plastic boxes and allowed to adjust to the environment for $1 \mathrm{~h}$. Using the up-down paradigm (Chaplan et al., 1994), mechanical sensitivity was assessed with a set of von Frey filaments. Based on preliminary experiments that characterized the threshold stimulus in untreated animals, the innocuous $0.4 \mathrm{mN}$ (\#2.44) filament, representing $50 \%$ of the threshold force, was used to detect mechanical allodynia. The filament was applied to the point of bending six times each to the dorsal surfaces of the left and right hindpaws. Positive responses included prolonged hindpaw withdrawal followed by licking or scratching. For each time point, the percentage response frequency of hindpaw withdrawal was expressed as follows: (number of positive responses) $/ 6 \times 100$ per hindpaw.

To assess motor coordination, we measured performance on the rotarod. All animals were pretrained $1 \mathrm{~h}$ before testing until they were able to remain on the rod for $30 \mathrm{~s}$ at $16 \mathrm{rpm}$. During testing, animals were placed on the rod, and the latency to fall off or the latency to complete two consecutive rolls (some animals grip the rod and roll around instead of falling) was recorded as the rod accelerated from 4 to $40 \mathrm{rpm}$. Separate groups of animals were used for each set of behavioral experiments, except for the evaluation of acute pain where TF and HP responses were taken from the same group of mice. In these experiments, HP and TF response latencies were alternately recorded in $10 \mathrm{~min}$ intervals for a total of three to four measurements.

Drug preparation and administration. Drugs were freshly prepared. Most of the compounds were purchased from Sigma except the following chemicals: Ro 25-6981 (Tocris Cookson, St. Louis, MO), Ro 63-1908 (Hoffmann-La Roche, Basel, Switzerland), and [(R)-[(S)-1-(4-bromophenyl)-ethylamino]-(2,3-dioxo-1,2,3,4-tetrahydroquinoxalin-5-yl)methyl]-phosphonic acid (NVP-AAM077) (Novartis, Basel, Switzerland). For systemic injection, drugs were injected at a volume of $0.1 \mathrm{ml}$ per $20 \mathrm{~g}$ of body weight, and an equivalent volume of saline was used as a control. Under ketamine and xylazine anesthesia, 24-gauge guide cannulas were implanted bilaterally into the ACC $(0.7 \mathrm{~mm}$ anterior to bregma, $\pm 0.4 \mathrm{~mm}$ lateral from the midline, $1.7 \mathrm{~mm}$ beneath the surface of the skull). Mice were given at least 2 weeks to recover after cannula implantation. For intra-ACC injections, mice were anesthetized with $2-3 \%$ halothane anesthesia in a gas mixture of $30 \% \mathrm{O}_{2}$ balanced with nitrogen and placed in a Kopf stereotaxic instrument (Kopf Instruments, Tujunga, CA). The 30-gauge injection cannula was $0.1 \mathrm{~mm}$ lower than the guide. The microinjection apparatus consisted of a Hamilton syringe ( 5 $\mathrm{ml}$ ) connected to an injector needle (30 gauge) by a thin polyethylene tube and motorized syringe pump. Ro 25-6981or Ro 63-1908 (0.01, 0.10 , or $1.0 \mu \mathrm{g} / 0.5 \mu \mathrm{l}$, in saline) was infused into each side of the ACC at a rate of $0.05 \mu \mathrm{l} / \mathrm{min}$; an equivalent volume of saline was used as a con- 
A
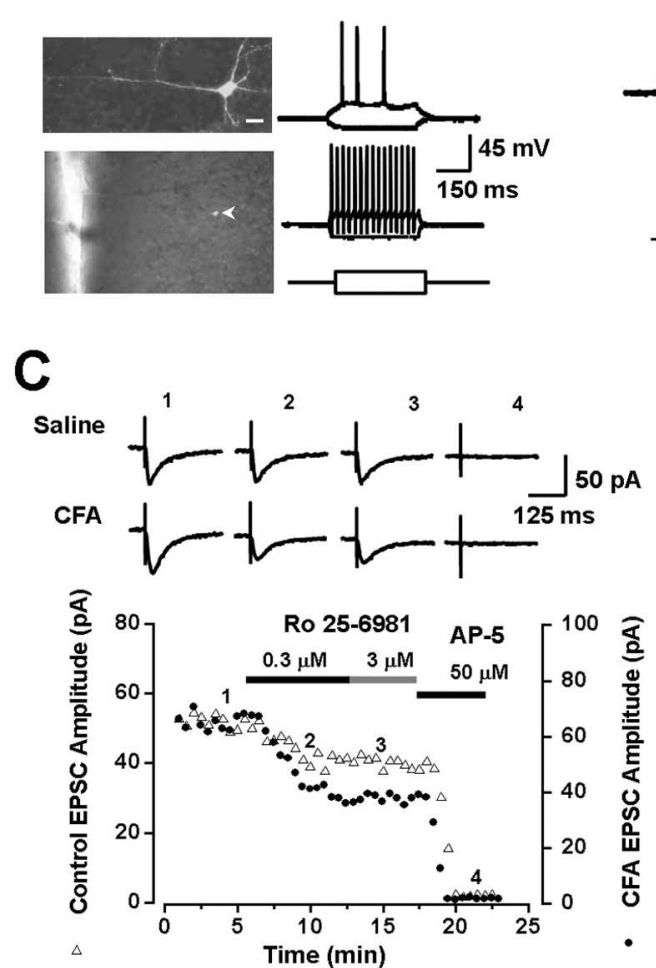

B

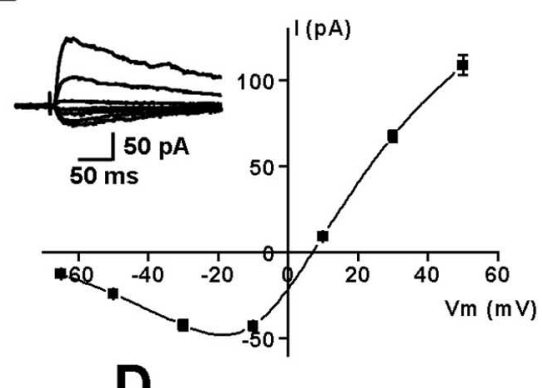

D

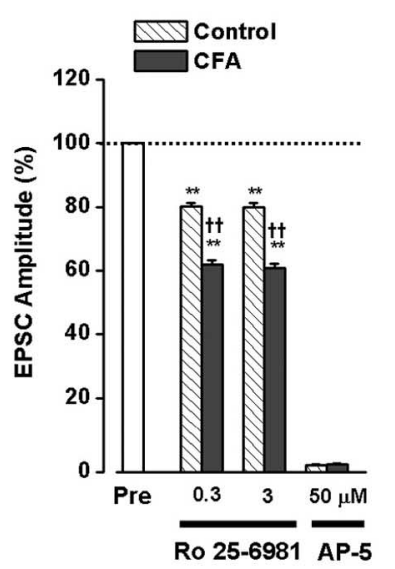

Figure 1. Increased NMDANR2B receptor-mediated postsynaptic currents in adult ACC neurons is shown after inflammation. $\boldsymbol{A}$, Confocal image of a pyramidal neuron in an adult ACC slice loaded with Lucifer yellow (top left). The arrow indicates the location of the neuron in the ACC slice (bottom left). Scale bar, $20 \mu \mathrm{m}$. When injected with current steps from -100 to $100 \mathrm{pA}$ in $400 \mathrm{~ms}$ (bottom right), the neuron shown at the left fired repetitive action potentials with frequency adaptation (top right). A minority of neurons recorded ( $n=4$ ) showed the fast-spike properties (middle right). $\boldsymbol{B}$, Current-voltage plot of the NMDA receptor EPSCs. The currents exhibited strong outward rectification and the reversal potential of the linear part was $4.4 \pm 2.0 \mathrm{mV}(n=6$ neurons $/ 5$ mice). Inset, NMDA receptor-mediated EPSCs recorded at holding potentials from -65 to $50 \mathrm{mV}$. Each trace represents the average of five consecutive recordings. C, A selective NR2B antagonist, Ro 25-6981, partially inhibited NMDA receptormediated EPSCs. The time course of changes in EPSC amplitude before and during the application of Ro $25-6981$ ( 0.3 and $3 \mu \mathrm{m})$ and AP-5 (50 $\mu \mathrm{m})$ in ACC neurons from both saline (control, $\Delta$ ) and CFA-injected $(O)$ mice is shown. Traces show the currents at different time points during application of drugs. Ro 25-6981 produced its maximal effect at 3 min after bath application, and a higher dose of Ro 25-6981 ( $3 \mu \mathrm{m}$ ) had no additional effects. The remaining currents can be totally blocked by AP-5 (50 $\mu \mathrm{M})$. D, Summary data of the effects Ro 25-6981 (0.3 and $3 \mu \mathrm{m}$ ) in ACC neurons of control (saline-injected) and CFA-injected mice. Ro 25-6981 produced significantly greater inhibitory effects on NMDA receptor-mediated EPSCs in ACC neurons in CFA-injected mice ( $n=9$ neurons $/ 8$ mice) than those in control adult mice ( $n=8$ neurons $/ 7$ mice). AP-5 (50 $\mu \mathrm{m})$ completely blocked the currents, confirming the currents are mediated NMDA receptors ( $n=5$ slices $/ 5$ mice). The double asterisks indicate significant difference from control, and the double daggers indicate significant difference from control NMDA receptor-mediated EPSCs. Error bars represent SEM.

trol. After injection, the microinjection needle was left in place for at least $5 \mathrm{~min}$.

Data analysis. Data are presented as mean \pm SEM. Statistical comparisons were performed using one- or two-way ANOVA with the post hoc Scheffe's $F$ test in immunocytochemical experiments or the StudentNewmann-Keuls test in behavioral experiments. Student's paired or unpaired $t$ tests were applied for comparisons between control and CFAtreated groups. In all cases, $p<0.05$ was considered statistically significant.

\section{Results}

Enhancement of NMDA receptor-mediated EPSCs in the ACC First, we wanted to determine whether NR2B subtype receptors contribute to NMDA receptor-mediated EPSCs in ACC neurons of normal adult mice. Conventional whole-cell patch-clamp recordings were performed from visually identified pyramidal cells in layer II/III of ACC slices of adult mice. In addition to visual identification, two additional parameters were used to confirm that recordings were performed from cortical pyramidal cells. First, we injected depolarizing currents into the neuron. In most cases, injection of depolarizing currents into neurons induced repetitive action potentials with frequency adaptation that is typical of the firing pattern of pyramidal neurons ( $n=74$ neurons $/ 30$ mice) (Bandrowski et al., 2001). The interneuron-like fast-spiking action potentials in response to depolarization were also observed in a minority of neurons recorded ( $n=4$ neurons $/ 4$ mice) (Fig. $1 A$ ). Second, lucifer yellow was loaded through the patch pipette, and morphological identification was studied under confocal laser-scanning microscopy. In all experiments, we confirmed that electrophysiological recordings were consistently performed from cortical pyramidal neurons (Fig. 1A).

Next, we pharmacologically isolated NMDA receptor-mediated EPSCs in ACC pyramidal neurons of adult mice. With local stimulation in the ACC, a slowdecaying inward EPSC was recorded in the presence of picrotoxin $(50 \mu \mathrm{M})$ and CNQX $(10 \mu \mathrm{M})$. This current was entirely and reversibly eliminated by the NMDA receptor antagonist AP-5 $(50 \mu \mathrm{M})$, indicating that the residual current was mediated by NMDA receptors. The currentvoltage relationship of the current showed a typical outward rectification with a reversal potential near $0 \mathrm{mV}(4.4 \pm 2.0 \mathrm{mV}$; $n=6$ neurons $/ 5$ mice) (Fig. $1 B$ ). To identify NR2B-senstitive NMDA receptors, the neurons were held at a potential of -30 $\mathrm{mV}$ to relieve the $\mathrm{Mg}^{2+}$ blockade. Bath application of the selective NMDA NR2B receptor antagonist Ro 25-6981 (0.3 $\mu \mathrm{M})$ significantly reduced the amplitude of NMDA EPSCs (to $80.2 \pm 1.0 \%$ of control; $p<0.01 ; n=9$ neurons $/ 8$ mice) (Fig. $1 C, D)$.

To determine whether NR2B is upregulated in ACC neurons after inflammation, we measured NR2B NMDA receptor-mediated currents in ACC pyramidal cells of CFA or saline-injected control mice. As predicted, the reduction of the EPSC amplitude by Ro 25-6981 $(0.3 \mu \mathrm{M})$ was significantly greater in ACC slices from CFAinjected mice (3-7 d after CFA; $62.0 \pm 1.2 \%$ of control, $n=8$ neurons $/ 7$ mice) compared with that of saline-injected mice $(80.2 \pm 1.0 \%$ of control, $n=9$ neurons/8 mice; $p<0.01)$ (Fig. $1 D)$. Application of a higher dose of Ro 25-6981 (3 $\mu \mathrm{M})$ did not produce greater inhibition of this reduction, suggesting that the dose of $0.3 \mu \mathrm{M}$ is sufficient to block the NR2B-containing NMDA receptor-mediated responses (Mutel et al., 1998) (Fig. 1C,D). The remaining EPSC in the presence of Ro 25-6981 was completely and reversibly blocked by AP-5 ( $n=5$ neurons/ 5 mice).

To detect possible time-dependent changes in NR2Bcontaining NMDA receptor-mediated responses, we also performed similar experiments at $1 \mathrm{~h}, 6 \mathrm{~h}$, and $1 \mathrm{~d}$ after CFA injec- 


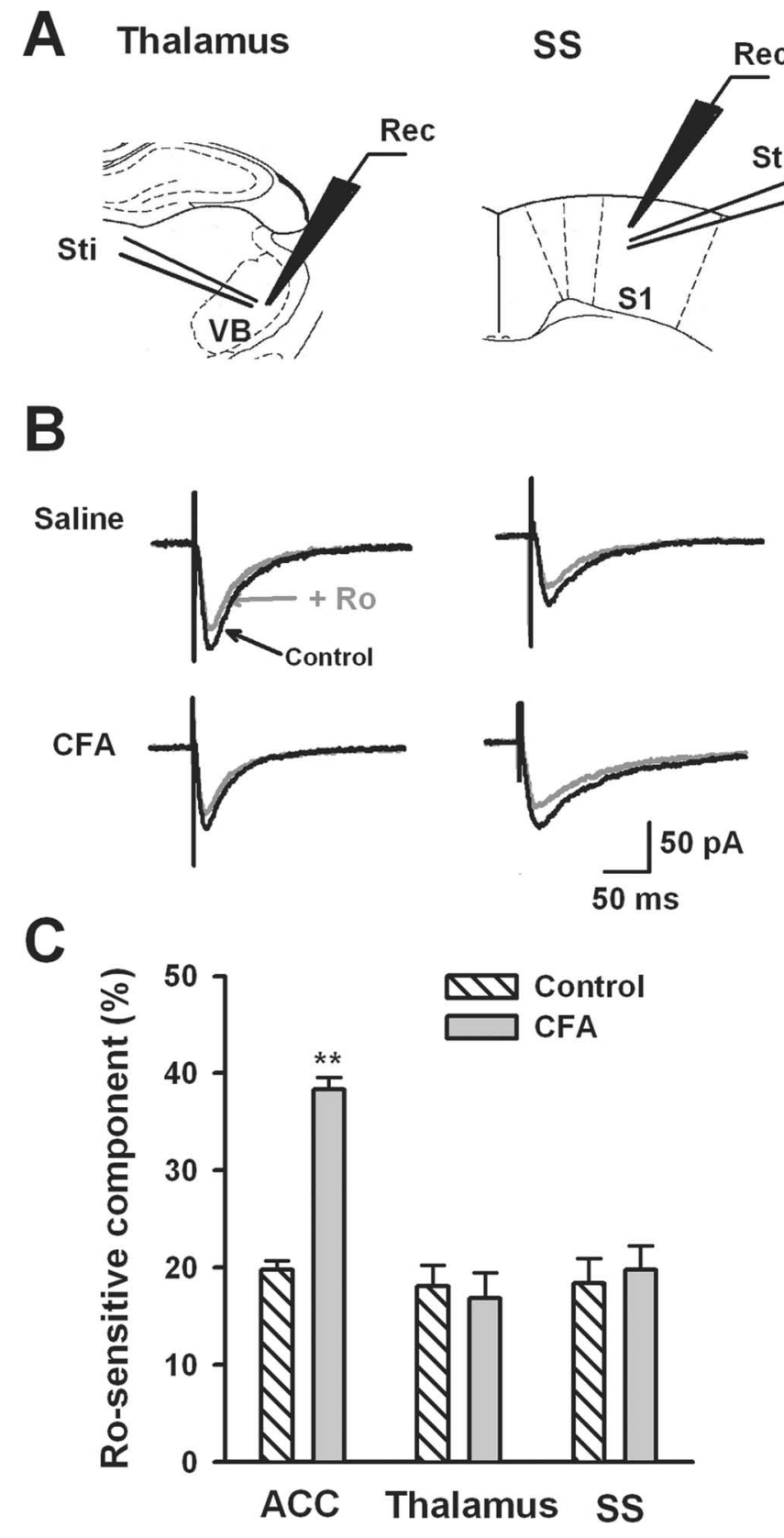

Figure 2. No increase in NMDA NR2B receptor-mediated currents in neurons of the thalamus or somatosensory cortex after inflammation. $\boldsymbol{A}$, Diagrams indicating the placement of stimulating (Sti) and recording (Rec) electrodes in the ventrobasal thalamus (VB) and somatosensory cortex (SS). B, Typical traces showing Ro 25-6981 (Ro;0.3 $\mu$ M) inhibited NMDA NR2B receptormediated currents in the thalamus and somatosensory cortex in saline (top) and CFA (bottom)injected mice. C, Summary results of the Ro 25-6981 effect in the ACC, ventrobasal thalamus, and somatosensory cortex, showing significant increase of Ro 25-6981-sensitive current in the ACC but not thalamus and somatosensory cortex. Error bars represent SEM.

tion. We found that NR2B-containing NMDA receptormediated responses were significantly increased at $1 \mathrm{~d}(n=5$ slices/ 3 mice $)$ but not $1 \mathrm{~h}(n=5$ slices $/ 4$ mice $)$ or $6 \mathrm{~h}(n=4$ slices/3 mice) after CFA injection, suggesting that CFA-induced NR2B upregulation is time dependent. Moreover, we studied NR2B-containing NMDA receptor-mediated responses in the ventrobasal thalamus and somatosensory cortex (Fig. 2). Our results showed that there was no change in synaptic NR2B currents after CFA inflammation in both areas (thalamus: $18.1 \pm$ $2.1 \%$ before vs $16.9 \pm 2.6 \%$ after; $n=5$ slices $/ 5$ mice; $p=0.72$;

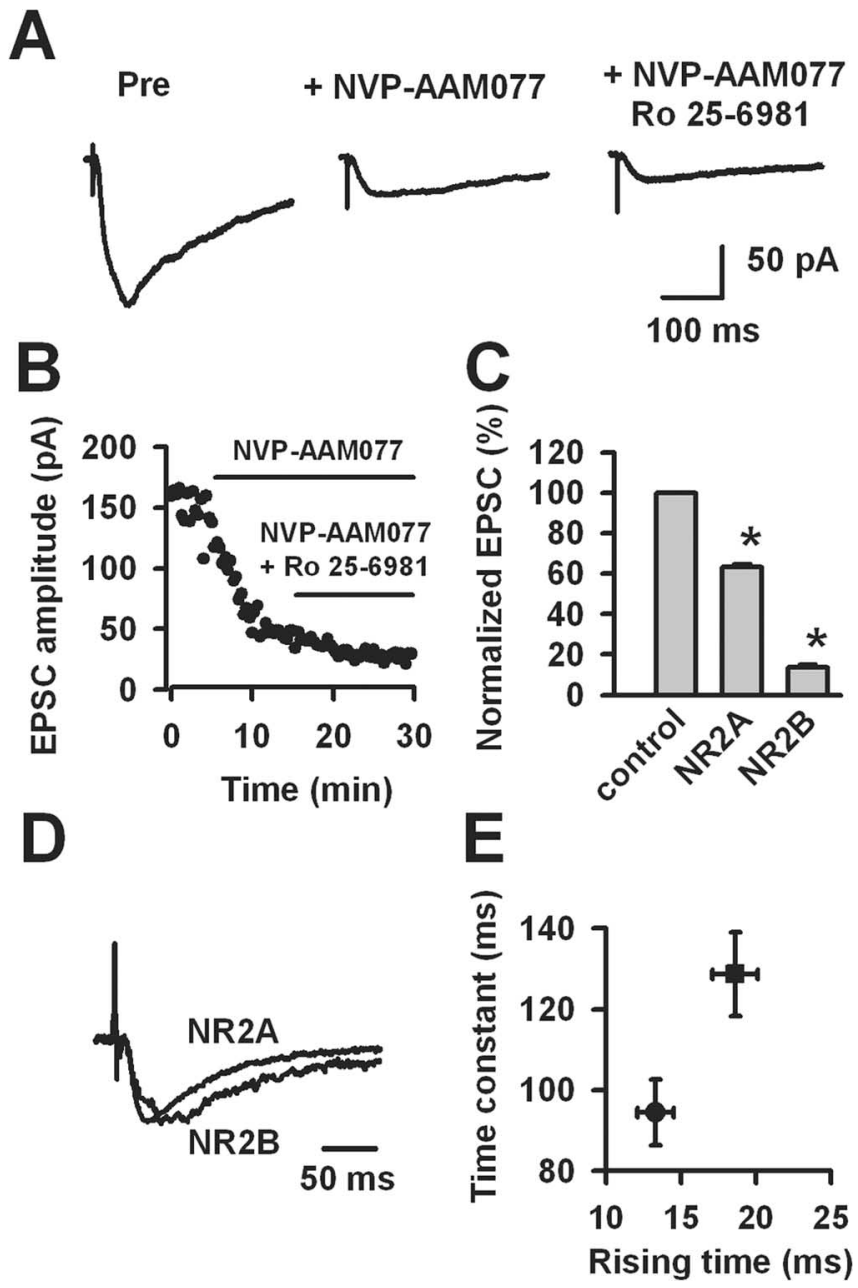

Figure 3. NMDA NR2A versus NR2B receptor-mediated currents in ACC neurons. $A$, NMDA receptor-mediated EPSCs recorded from ACC neurons in saline solution, $10 \mathrm{~min}$ after the addition of a selective NR2A antagonist NVP-AAM077 $(0.4 \mu \mathrm{M})$ and $10 \mathrm{~min}$ after the addition of a selective NR2B antagonist Ro 25-6981 (0.3 $\mu \mathrm{m})$. Pre, Before drug application. B, Peak EPSC amplitude versus time for the traces shown in $\boldsymbol{A}$. C, Summarized data showing the contribution of NMDA NR2A $(n=6)$ and NR2B $(n=6)$-mediated currents in ACC neurons. The asterisk indicates a significant difference from total NMDA receptor-mediated EPSCS. D, The NR2B EPSC scaled to the peak of the NR2A EPSC. The NR2B-mediated EPSCs showed slower kinetics compared with NR2A-mediated EPSCS. E, Time constant of EPSC decay versus the rising time (1090\%) for EPSCs mediated by NR2A (circle) and NR2B (square) component. Error bars represent SEM.

somatosensory cortex: $18.4 \pm 2.5 \%$ before vs $19.8 \pm 2.4 \%$ after; $n=6$ slices $/ 5$ mice; $p=0.70$ ). These results suggest that the changes in NR2B receptors are relatively regionally selective.

Finally, we used a selective antagonist of NR2A-containing NMDA receptors, NVP-AAM077 (Liu et al., 2004; Massey et al., 2004), to further test whether Ro 25-6981 acts on NR2Bcontaining NMDA receptors in the ACC neurons. After recording the total NMDA receptor-mediated EPSCs in ACC pyramidal neurons, NR2A and NR2B subunit-mediated currents were isolated by sequential application of the NR2A specific antagonist NVP-AAM077 $(0.4 \mu \mathrm{M})$ and the NR2B-specific antagonist Ro 25-6981 $(0.3 \mu \mathrm{M})$ (Fig. 3A,B). NVP-AAM077 depressed total EPSCs by $63.2 \pm 1.7 \%(n=6$ neurons $/ 3$ mice) (Fig. $3 C)$ and subsequent application of Ro 25-6981 further depressed currents to $13.7 \pm 1.4 \%(n=6$ neurons $/ 3$ mice $)$ (Fig. $3 C)$. It has been reported that NR2A and NR2B receptor-mediated currents have different kinetics (see Introduction). To compare NR2A and 

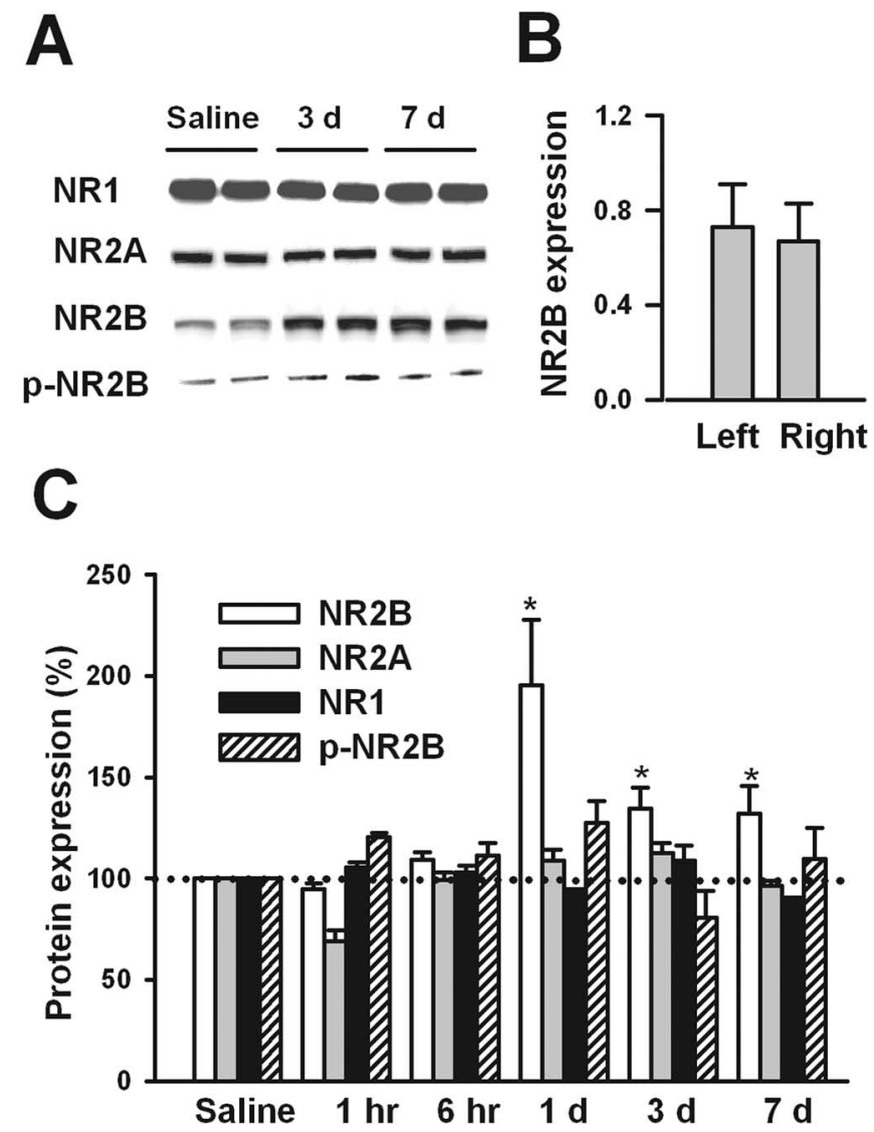

Figure 4. Enhanced expression of NMDA NR2B receptors in the ACC after inflammation. $A$, Western blot results showed that the expression level of NR2B, but not NR1, NR2A, or phosphorylated NR2B, was increased in the ACC 1,3 , and $7 \mathrm{~d}$ after CFA injection $(n=4-8$ mice for each group). $B$, Baseline expression levels of NR2B in the left ACC and right ACC were identical ( $n=$ 7 mice; arbitrary unit normalized by actin). C, Summary of NMDA NR2B, NR2A, NR1, and phosphorylated NR2B expression in the ACC at different time points after CFA injection $(n=3-8$ mice). ${ }^{*} p<0.05$, significant different from saline-injected control group. Error bars represent SEM.

NR2B kinetics, we subtracted NR2A- and NR2B-sensitive components from the total NMDA EPSC. We found that the rising time $(10-90 \%)$ and decay time constant $(\tau)$ of NR2B-mediated EPSCs were significantly longer than those of NR2A-mediated currents in ACC pyramids neurons (rising time: $18.6 \pm 1.5 \mathrm{~ms}$ vs $13.3 \pm 1.2 \mathrm{~ms} ; p<0.05 ; n=10$ neurons/4 mice; $\tau: 128.7 \pm 10.4$ ms vs $94.5 \pm 8.2 \mathrm{~ms} ; p<0.05 ; n=10$ neurons $/ 4$ mice) (Fig. $3 D, E)$.

\section{Upregulation of NR2B expression after injury}

To evaluate NR2B expression in the ACC, we used Western blot analysis. The level of NR2B expression in the ACC was significantly increased at 1,3 , and $7 \mathrm{~d}$ after the CFA injection $(n=8$ mice for each time point; for each time-point, $p<0.05$ compared with saline-treated groups) (Fig. $4 A, C$ ). The increase in NR2B expression was time dependent, because there was no significant change in NR2B protein level at 1 or $6 \mathrm{~h}(n=3$ mice) after CFA injection compared with saline-injected mice $(n=3$ mice) (Fig. $4 C)$. Recent studies have shown an increase in tyrosine phosphorylation of NR2B after inflammation in the spinal cord (Guo et al., 2002, 2004). Thus, we also wanted to see whether there is a change in the tyrosine phosphorylation state of NR2B in the ACC after inflammation. The level of tyrosine phosphorylation of NR2B remained unchanged in the ACC after CFA-induced inflamma-
A

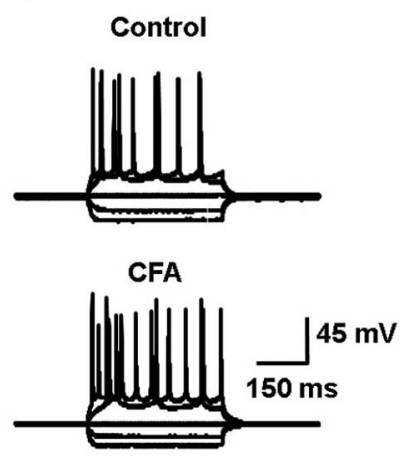

B

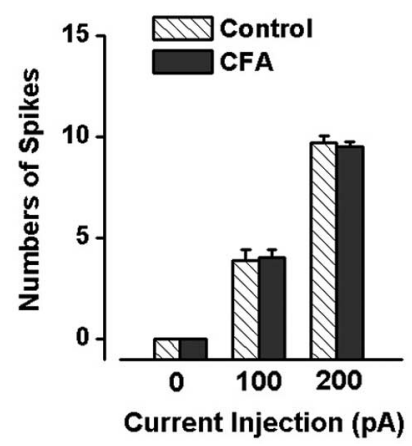

Figure 5. The neuronal excitability of ACC neurons after CFA inflammation. A, Spike properties did not change after CFA inflammation compared with saline-injected control mice. Example traces show the current injection from - 200 to $200 \mathrm{pA}$ with $100 \mathrm{pAsteps}$ for $400 \mathrm{~ms}$ induced repetitive action potentials in neurons of control and CFA-injected mice. $\boldsymbol{B}$, Statistical results showing that there is no significance change in the number of spikes with either 100 or $200 \mathrm{pA}$ injected current in control mice ( $n=22$ neurons/12 mice) and CFA-injected mice ( $n=22$ neurons $/ 15$ mice). Error bars represent SEM.

tion compared with saline-treated control levels $(n=3-5$ mice; $p>0.05$ compared with saline-treated group) (Fig. 4A,C).

We also performed Western blot analysis for the other NMDA receptor subunits, NR1 and NR2A, and did not see any significant increase at $3 \mathrm{~d}(n=4$ mice $)$ and $7 \mathrm{~d}(n=4$ mice $)$ after CFA injection (Fig. $4 A, C$ ). These findings indicate that changes in NMDA receptors are selective for NR2B subunits in the ACC. Quantitative analysis of NR2B expression in the ACC showed that NR2B in the ACC contralateral and ipsilateral to the injected hindpaw had similar increases $(n=3-4$ mice $)$. Furthermore, baseline expression levels of NR2B in the left ACC and right ACC were identical ( $n=7$ mice) (Fig. $4 B$ ).

Previous studies demonstrated that some hippocampal neurons respond to noxious stimuli, providing a possible candidate for pain-related spatial memory (Wei et al., 2000). We next wanted to know whether NR2B levels in the hippocampus might be affected after inflammation. We found no significant increase in NR2B expression in the hippocampus of the same animals with increased NR2B levels in the ACC $3 \mathrm{~d}$ after CFA injection (mean, $84.3 \pm 3.1 \%$ of saline-treated; $n=4$ mice; $p<0.05$ compared with saline-treated group). Together, these results indicate that the increase in NMDA receptors is relatively subunit (primarily for NR2B but not NR2A) and regionally selective (primarily in the ACC).

\section{Neuronal excitability of ACC neurons after injury}

To examine possible changes in cingulate pyramidal neuron excitability after inflammation, we measured spike responses to postsynaptic current injection. We did not find any significant change in the number of spikes in neurons from CFA-injected or saline-injected control animals with injections of either 100 or 200 pA ( $n=22$ neurons/10-15 mice for each group) (Fig. 5). In addition, there was no difference in the resting potential between saline $(-63.1 \pm 3.1 \mathrm{mV} ; n=25$ neurons $/ 15$ mice $)$ and CFAinjected mice $(-64.8 \pm 4.0 \mathrm{mV} ; n=22$ neurons $/ 10$ mice; $p>$ $0.05)$. The reversal potential of NMDA EPSCs was also similar between saline ( $4.4 \pm 2.0 \mathrm{mV} ; n=6$ neurons $/ 5$ mice $)$ and CFAinjected mice $(4.6 \pm 1.8 \mathrm{mV} ; n=5$ neurons $/ 5$ mice; $p>0.05)$.

NMDA receptor-mediated responses in freely moving mice To measure NMDA receptor-mediated responses in the ACC under more physiological conditions, field potential recordings 
from conscious, freely moving mice were performed. Animals were implanted with an electrode in both sides of the ACC, and electrophysiological measurements were performed 2 weeks after surgery. The field EPSPs (fEPSPs) from one side of the ACC were induced by the direct focal electrical stimulation of the ACC in the other hemisphere (Fig. 6A,B). The fEPSPs uniformly consisted of both a fast and a slow component of fEPSP $(n=20$ mice), with the latter one more sensitive to AP-5, showing the involvement of NMDA receptors in the slow responses $(n=6$ mice) (Fig. 6B). Does the increase in NR2B expression result in a functional change in NMDA-mediated fEPSPs after persistent inflammatory pain? To address this question, fEPSPs were recorded from freely moving mice before, $1 \mathrm{~d}$, and $3 \mathrm{~d}$ after CFA injection, times when reliable behavioral allodynia was observed (Wei et al., 2001, 2002). As shown in Figure 6, $C$ and D, we found that fEPSPs were enhanced after the injection. Particularly, NMDA receptor-contributed slow fEPSPs were significantly potentiated both 1 and $3 \mathrm{~d}$ after CFA injection $(n=5$ mice). In contrast, fEPSPs showed no change 1 or $3 \mathrm{~d}$ after injection in saline-injected control mice ( $n=6$ mice) (Fig. $6 C$ ). Unlike slow fEPSPs, fast fEPSPs did not show any significant change at $1 \mathrm{~d}$ after CFA injection in the same mice (Fig. 5C,D). At $3 \mathrm{~d}$ after CFA injection, however, fast fEPSPs were also significantly increased $(n=5$ mice; $p<0.05)$ compared with saline-injected mice $(n=$ 6 mice). Furthermore, systemic injection of Ro 25-6981 (5 mg/ $\mathrm{kg}$, i.p.) blocked the enhancement of slow fEPSP responses $(p<$ 0.05), whereas the fast component of fEPSPs was not significantly affected in the same animals $(n=5$ mice) (Fig. $6 D)$, suggesting that the increased response after peripheral CFA injection was primarily mediated by NMDA receptor containing NR2B subunit.

\section{NMDA receptor-mediated slow responses in}

\section{ACC-ACC synapses}

Because of the slow onset of NMDA receptor-mediated fEPSPs recorded from freely moving mice, we predicted that the slow responses are likely to be polysynaptic. To test this possibility, we performed field recordings from adult ACC slices containing both sides of ACC connected by callosal projections (Fig. 7A). In vitro slice preparations allowed us to perform better pharmacological blockade of NMDA receptors. Similar to field recordings in freely moving mice, electrical stimulation of the ACC induced fast fEPSPs followed by slow fEPSPs in the contralateral ACC (Fig. $7 B)$. Bath application of AP-5 $(50-100 \mu \mathrm{M})$ selectively blocked the slow fEPSPs (Fig. 7D), indicating that the slow fEPSPs are mediated by NMDA receptors ( $n=6$ slices $/ 5$ mice). Interestingly, bath application of an AMPA/kainate receptor antagonist, CNQX $(20 \mu \mathrm{M})$, blocked all responses $(n=5$ slices $/ 5$ mice) (Fig. 7C), confirming that NMDA receptor-mediated slow responses may be polysynaptic. However, we cannot rule out the possibility that NMDA receptor-mediated fEPSPs may be monosynaptic. CNQX may block endogenous AMPA receptor activation that depolarizes the postsynaptic cell sufficiently to allow relief of the $\mathrm{Mg}^{2+}$ block of NMDA receptors, and the blockade of this relief leads to inhibition of NMDA receptor-mediated responses.

Behavioral nociceptive studies of NR2B receptor antagonists Transgenic overexpression of NR2B in forebrain areas enhanced inflammatory pain in mice (Wei et al., 2001). Similarly, our results show that NR2B expression is increased in the ACC after inflammatory pain, suggesting that inhibition of the NR2B subunit may alter inflammation-induced behavioral responses in
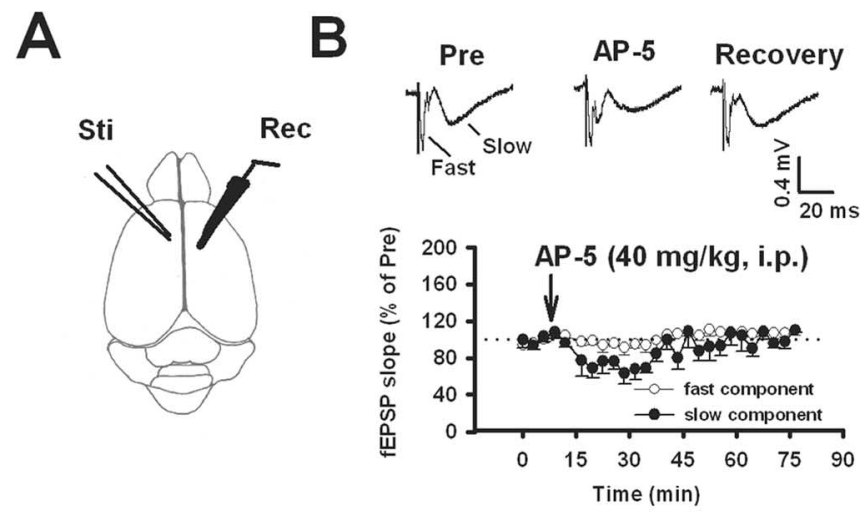

C
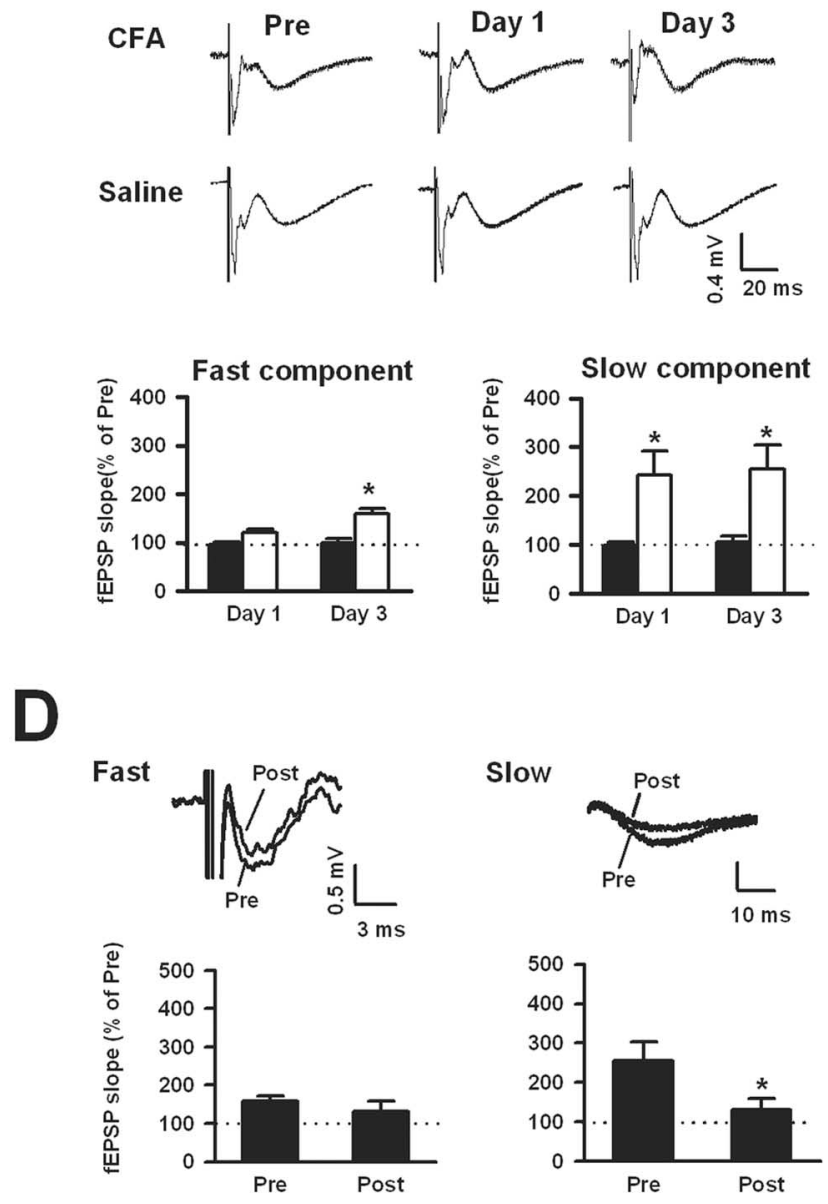

Figure 6. Enhanced $A C C-A C C$ evoked responses after CFA inflammation in freely moving mice. $\boldsymbol{A}$, Diagram of a mouse brain showing the placement of recording and stimulating electrodes in freely moving mice. Rec, Recording electrode; Sti, stimulating electrode. $\boldsymbol{B}$, Field EPSPS recorded from one side of the ACC in response to stimulation of the ACC in the opposite hemisphere. A fast fEPSP is followed by a slow fEPSP. Systemic administration of the NMDA receptor antagonist AP-5 (40 mg/kg, i.p.; $n=6$ mice) significantly reduced the slow fEPSP (above). Summarized data of the effects of AP-5 on fast and slow fEPSPs is shown below. $C$, Example traces of fEPSPs recorded before (Pre), $1 \mathrm{~d}$, or $3 \mathrm{~d}$ after (FA or saline injection. Summarized data showing the significant increase of slow fEPSPs both 1 and $3 \mathrm{~d}$ after CFA injection (CFA, open bars, $n=5$ mice; saline, filled bars, $n=6$ mice; $p<0.05$ between 2 groups). The fast fEPSPs also showed changes $3 \mathrm{~d}$ after CFA ( $p<0.05$ ) (below). D, Systemic administration of the NR2B receptor antagonist Ro $25-6981$ (5 mg/kg, i.p.; $n=5$ mice) blocked the enhanced slow responses in the ACC at $3 \mathrm{~d}$ after CFA injection. Insets, Traces of evoked responses from a freely moving mouse before (Pre) and after (Post) Ro 25-6981 at 3 d after CFA inflammation. Error bars represent SEM. 


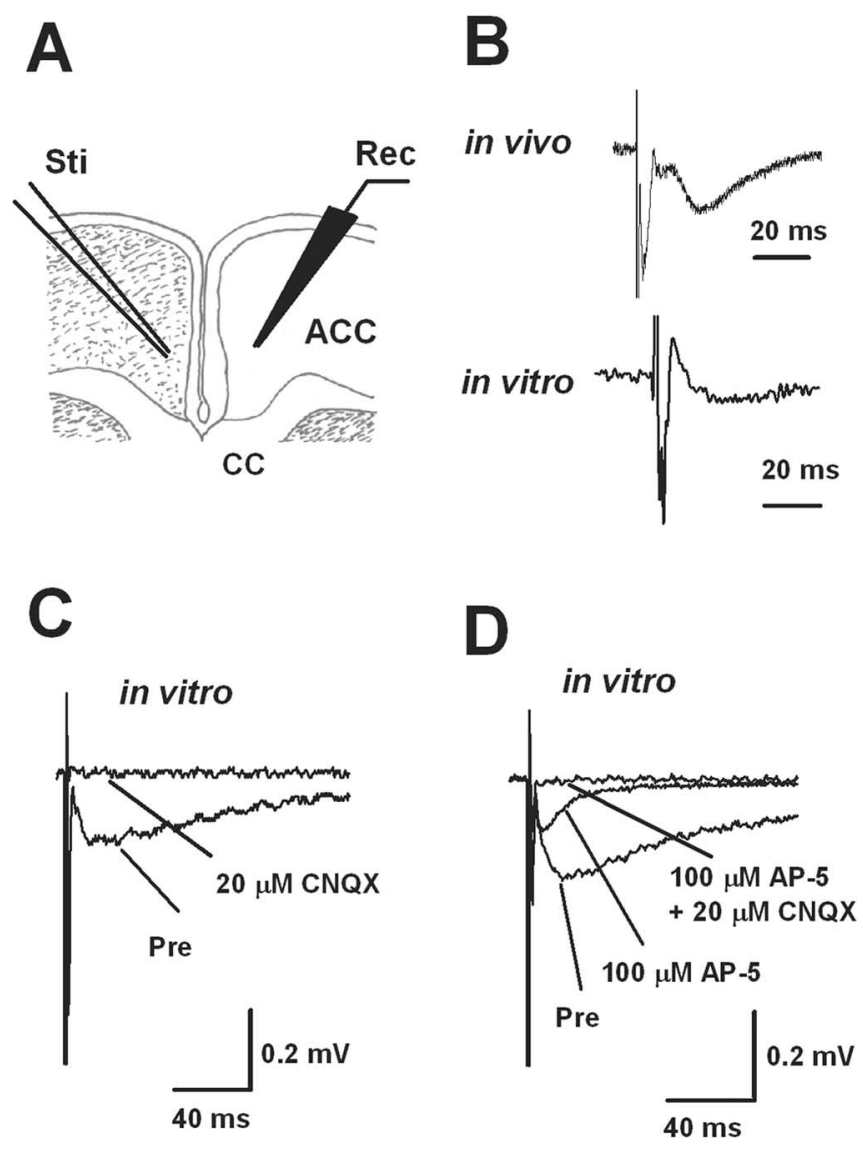

Figure 7. Polysynaptic slow field EPSPs recorded in ACC-ACC synapses in brain slices of adult mice. $A$, Diagram of the placement of stimulating and recording electrodes. CC, Corpus callosum; Rec, recording electrode; Sti, stimulating electrode. $\boldsymbol{B}$, Comparison of slow responses recorded from a freely moving mouse (in vivo, top trace) and a brain slice (in vitro, bottom trace). In both examples, slow responses followed fast responses with a similar time delay. C, Bath application of the selective AMPA/kainate receptor antagonist CNQX (20 $\mu \mathrm{m})$ completely blocked fast and slow responses ( $n=5$ slices $/ 5$ mice). $D$, Bath application of the NMDA receptor antagonist AP-5 $(100 \mu \mathrm{M})$ selectively blocked slow fEPSPs, and coapplication of CNQX (20 $\mu \mathrm{M})$ and AP-5 completely blocked fast and slow responses.

mice. To test this hypothesis, we microinjected a selective NR2B antagonist (Ro 25-6981) bilaterally into the ACC (Lynch et al., 2001; Malherbe et al., 2003) and evaluated the effects of Ro 256981 on mechanical allodynia induced by CFA inflammation. Three days after CFA injection, mice demonstrated typical hypersensitive responses to non-noxious mechanical stimulation. After bilateral microinjection of $1 \mu \mathrm{g} / 0.5 \mu \mathrm{l}(5.3 \mathrm{~mm})$ Ro 25-6981 $\left(\mathrm{IC}_{50}=0.009 \mu \mathrm{M}\right)$ (Fischer et al., 1997) into the ACC $(n=6$ mice), mechanical allodynia was significantly reduced (Fig. $8 \mathrm{~A}$ ). We also evaluated $1 \mu \mathrm{g} / 0.5 \mu \mathrm{l}(5.0 \mathrm{~mm})$ Ro 63-1908 $\left(\mathrm{IC}_{50}=\right.$ $0.003 \mu \mathrm{M}$ ) (Gill et al., 2002), another NR2B inhibitor (Gill et al., 2002; Higgins et al., 2003) and obtained similar results $(n=5$ mice) (Fig. $8 \mathrm{~A}$ ). Saline was microinjected bilaterally as a control ( $n=3-5$ mice) and did not have a significant effect on allodynia (Fig. 8A). To address the role of NR2B in the early behavioral responses to CFA inflammation, we also microinjected Ro 256981 into the ACC of mice $6 \mathrm{~h}$ after CFA injection. Mechanical allodynia was similar between mice receiving Ro 25-6981(1 $\mu \mathrm{g} /$ $0.5 \mu \mathrm{l} ; n=7)$ and saline injection $(n=6 ; p=0.73$ ipsilateral; $p=$ 0.64 contralateral). Similar results were found at $1 \mathrm{~h}$ after CFA injection $(n=4)$. Ro $25-6981$ had no effect on CFA-induced allodynia when injected into the ACC at the low doses of $0.01 \mu \mathrm{g}$ $(p=0.47)$ and $0.1 \mu \mathrm{g}(p=0.33) 3 \mathrm{~d}$ after CFA injection. To
A

\section{intra-ACC injection ( 3 days after CFA)}
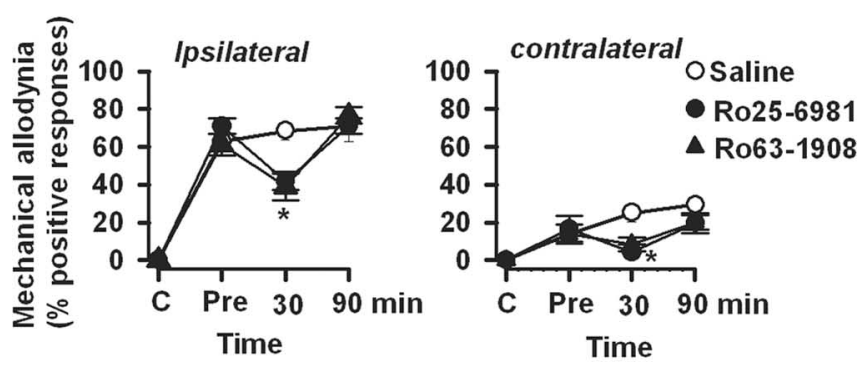

\section{Systemic injection ( 3 days after CFA)}
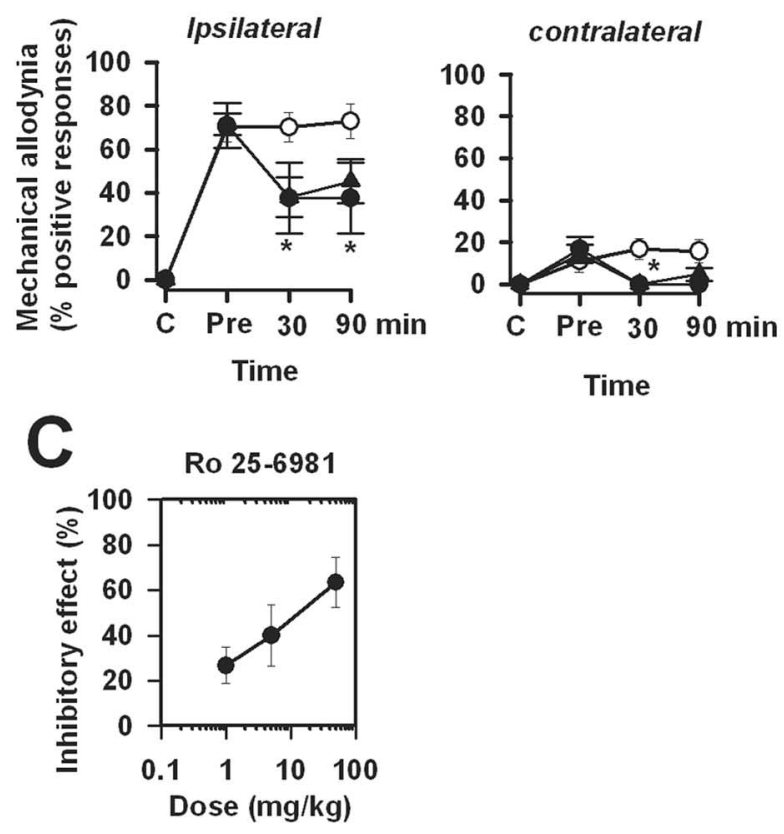

Figure 8. Effects of selective NMDA NR2B receptor antagonists on inflammation-induced behavioral allodynia, acute pain, and motor function. $A$, The NR2B receptor antagonists Ro 25-6981 ( $n=6$ mice) or Ro 63-1908 ( $n=5$ mice) microinjected bilaterally into the ACC (1 $\mu \mathrm{g} / 0.5 \mu \mathrm{l}$ for each side) significantly reduced mechanical allodynia at $3 \mathrm{~d}$ after (FA injection. Responses were recorded before CFA injection, previous to drug or saline injection (Pre), and for $30-90 \mathrm{~min}$ afterward. Allodynia detected from the uninjected hindpaw was also reduced. ${ }^{*} p<0.05$. B, Systemic administration of Ro $25-6981$ (5 mg/kg, i.p.; $n=6$ mice) or Ro 63-1908 (5 mg/kg, i.p.; $n=5$ mice) significantly reduced mechanical allodynia bilaterally. $C$, Dose-dependent response curve for 1-50 mg/kg Ro 25-6981 showing the percentage of the inhibitory effect on behavioral allodynia ( $n=5-8$ mice). Error bars represent SEM.

determine whether NR2B antagonists may alter acute thermal sensitivity, we tested withdrawal responses to acute noxious stimuli after administration of either Ro 25-6981 ( $1 \mu \mathrm{g} / 0.5 \mu \mathrm{l})$ or saline bilaterally into the ACC. Ro 25-6981 had no significant effect on behavioral responses in the TF and HP tests or on responses to mechanical stimuli $(n=5-8$ mice $)$ when compared with saline controls (data not shown).

One important route for drug delivery in a clinical setting is through systemic administration. Previous studies showed that NR2B receptor antagonists, including Ro 25-6981, produced antinociceptive effects when injected intraperitoneally (i.p.) in adult rats (Boyce et al., 1999). To determine whether Ro 25-6981 administered systemically may also reduce CFA-induced allodynia in mice, we injected Ro 25-6981 (5 mg/kg, i.p.; $n=6) 3 \mathrm{~d}$ 
after CFA injection. Behavioral allodynia was significantly reduced (Fig. $8 B$ ) compared with saline-injected mice $(n=6)$, and similar results were obtained with Ro 63-1908 (5 mg/kg; $n=5$ mice) (Fig. 8 B). As above, we administered Ro 25-6981 (5 mg/kg; $n=5) 6 \mathrm{~h}$ after CFA injection and found no significant difference in responses when compared with saline controls $(p=0.77$ ipsilateral; $p=0.82$ contralateral). We also found that Ro 25-6981 (5 $\mathrm{mg} / \mathrm{kg}$, i.p.) did not significantly affect behavioral responses to acute noxious stimuli in the TF $(n=6 ; p=0.54)$ and $\operatorname{HP}(n=6$; $p=0.55)$ tests and did not affect mechanical withdrawal $(n=8$; $p=0.60$ ). To determine whether treatment with Ro 25-6981 affects motor coordination in mice, we measured their performance in the rotarod test. We found that Ro 25-6981 (5 or 50 $\mathrm{mg} / \mathrm{kg}$, i.p.) did not significantly affect motor performance in normal mice at antinociceptive doses $(n=5$, saline; $n=6,5$ $\mathrm{mg} / \mathrm{kg} ; n=4,50 \mathrm{mg} / \mathrm{kg} ; p=0.40$ ).

\section{Discussion}

Our study provides the first evidence that the upregulation of NMDA NR2B receptors in the ACC contributes to inflammationrelated persistent pain. After persistent inflammation, the expression of NMDA NR2B receptors in the ACC was upregulated. Consistently, microinjection into the ACC and systemic administration of NR2B receptor-selective antagonists inhibited behavioral responses to peripheral inflammation. These results are in good accordance with our previous report showing that NR2B forebrain overexpression selectively enhanced inflammationrelated persistent pain in transgenic mice (Wei et al., 2001). Furthermore, we believe that the present study provides critical evidence that NMDA NR2B receptors undergo long-term plastic changes in the brain after injury.

Although we do not have evidence for the molecular signaling pathways responsible for NR2B upregulation in the ACC, we demonstrate that NR2B is upregulated in forebrain neurons after peripheral inflammation. We believe that this NR2B receptor upregulation is likely to be reliant on activity-dependent mechanisms. Several lines of evidence support this prediction: (1) the molecular motor protein kinesin protein 17 has been shown to be involved in the active transport of NR2B (Setou et al., 2000; Wong et al., 2002; Guillaud et al., 2003); (2) NR2B, mRNA, and protein are highly expressed in ACC neurons (Wei et al., 2001); and (3) NR2B contains a cAMP response element-binding protein (CREB) binding domain, which may couple increases in intracellular calcium with the increase in NR2B expression. Because NMDA receptors play an important role in activitydependent plasticity in the ACC, we suggest that NR2B may be regulated through NMDA-calcium-CaM-dependent signaling pathways. The activation of NMDA receptors triggers postsynaptic calcium, leading to the activation of calcium-stimulated CREB in the ACC after injury (Wei et al., 2002). Because NR2B contains a CREB-binding domain, it is likely that NR2B may be activated downstream from the CREB signaling pathway through the activation of NMDA receptors. Electrophysiological results showed that NR2B receptors contribute to NMDA receptor-mediated responses in ACC neurons of adult animals. Despite the upregulation in NR2B subunit expression, our results show that the tyrosine phosphorylation state of NR2B was unchanged in the ACC after inflammation. This suggests that upregulation, not phosphorylation, of NR2B may be involved in the enhancement of NMDA receptor-mediated currents in the ACC after inflammation. This may be because of the low basal NR2B subunit phosphorylation seen in the ACC compared with the hippocampus (Zhao et al., 2005). However, we point out that these results do not rule out a possible role for phosphorylated NR2B in inflammatory pain.

ACC neurons are reported to respond to peripheral stimulation bilaterally, which is consistent with the fact that ACC neurons have a sensory receptive field that covers the whole surface of the body (Sikes and Vogt, 1992; Traub et al., 1996; Hutchison et al., 1999; Wei et al., 1999; Wei and Zhuo, 2001). A recent study in the hippocampus reported that NR2B distribution showed lateral differences (Kawakami et al., 2003). In the present study, we compared the amount of NR2B protein expression between the left and right hemispheres and did not detect any significant difference. In addition, we showed that inflammation caused similar increases in the ACC ipsilateral or contralateral to the injection site. These findings are in agreement with our previous electrophysiological observation that a single digit amputation caused bilateral expression of immediate early genes in the ACC, bilateral loss of long-term depression, and bilateral synaptic potentiation (Wei et al., 1999; Wei and Zhuo, 2001). In addition to the fact that ACC neurons receive inputs from both sides of the body, dense connecting fibers between the two sides of the ACC may also provide an additional mechanism for bilateral changes in the ACC (Ramon y Cajal, 1995). Our electrophysiological data from freely moving mice showed that indeed ACC-ACC synapses are well connected by both postsynaptic fast currents mediated by AMPA receptors and slow currents that are mediated by polysynaptic NMDA receptors. The significant slow component of NMDA receptor-mediated fEPSPs is unique, because in most central synapses, NMDA receptors are not activated in resting conditions (Liauw et al., 2003). Furthermore, we detected an increase in NR2B receptor contribution to slow responses in the ACC-ACC synapses, providing a novel neural mechanism for information processing in the higher brain regions. Reciprocal innervations between ACC neurons in the two hemispheres may store long-term pathological neural changes in the brain in addition to their widespread connections with other central nuclei.

How does the increase in NR2B subtype receptors in the ACC influence neuronal activity? There are at least several possibilities. First, increased NR2B subtype receptors may affect NMDA receptor-mediated currents as reported previously in NR2Boverexpressing transgenic mice (Tang et al., 1999; Wei et al., 2001). NR1 is reportedly synthesized in considerable excess (estimated to be $\sim 10$-fold) compared with NR2, based on the finding that one pool of NR1 was not assembled with NR2, which showed rapid degradation (Huh and Wenthold, 1999; Wenthold et al., 2003). Consistent with this idea, overexpression of NR2, but not NR1, increased functional receptors in cultured granule cells (Prybylowski et al., 2002). Moreover, overexpression of NR2B in the mouse forebrain increased synaptic NMDA currents in the hippocampus and cortex (Tang et al., 1999; Wei et al., 1999). In the present study, we observed the selective upregulation of NR2B, but not NR1, after CFA inflammation. One possible explanation is that the upregulated NR2B can form functional NMDA receptors with the excessive NR1. Our electrophysiological recordings of NMDA receptor-mediated EPSCs and their increased sensitivity to the selective NR2B receptor antagonist Ro25-6891 strongly support this possibility. Altered NMDA receptor function may also lead to the enhancement of synaptic plasticity, such as long-term potentiation and behavioral persistent pain (Wei et al., 2001). Second, NR2B overexpression may affect NMDA receptor internalization and stability in the synapses of the ACC neurons (Roche et al., 2001). Third, overexpression of NR2B may enhance NMDA receptor-mediated extracellular signal-regulated kinase (ERK) activation through its 
interaction with RasGRF1 (Krapivinsky et al., 2003). The NMDA-ERK signaling pathways have been implicated in inflammation-related central plasticity (Ji et al., 2002).

Results from our behavioral studies using the NR2B receptor antagonists Ro 25-6891 and Ro 63-1908 showed that local inhibition of NR2B in the ACC produced a significant reduction in behavioral allodynia. We showed that intraperitoneal injection of two different NR2B receptor antagonists produced significant analgesic effects on inflammation-related mechanical allodynia. The concentration used for the two drugs is much higher than the $\mathrm{IC}_{50}$ value for inhibition of NR2B-containing receptors. However, it is a general technical problem for microinjection that the local concentration and diffusion of the drugs are difficult to quantify. Therefore, we did not know the estimated concentration for the drugs after microinjection in the ACC. There were no obvious abnormal behaviors in mice receiving the NMDA receptor antagonists, and they could not be visually distinguished from saline-injected controls. It is worthwhile to point out that our results do not rule out the possible contribution of NMDA receptors in the spinal cord dorsal horn on behavioral responses after systemic administration of NR2B antagonists. Indeed, recent studies showed that the voltage dependence of NMDA receptors in the spinal cord dorsal horn may undergo plastic changes after inflammation (Guo and Huang, 2001), although the potential change in NR2B receptors has not been explored. Therefore, it is more likely that CFA inflammation causes a series of plastic changes along the somatosensory pathway, including the dorsal root ganglion, spinal dorsal horn and ACC neurons. The integration of plastic changes along the sensory neuronal network eventually leads to long-term behavioral sensitization as we found in freely moving mice.

In summary, we provide strong evidence for a link between NMDA NR2B receptors in the ACC and persistent inflammatory pain. Drugs targeted at NMDA NR2B receptors may help us to control chronic pain in animals and humans.

\section{References}

Bandrowski AE, Aramakis VB, Moore SL, Ashe JH (2001) Metabotropic glutamate receptors modify ionotropic glutamate responses in neocortical pyramidal cells and interneurons. Exp Brain Res 136:25-40.

Bliss TV (1999) Young receptors make smart mice. Nature 401:25-27.

Boyce S, Wyatt A, Webb JK, O’Donnell R, Mason G, Rigby M, Sirinathsinghji D, Hill RG, Rupniak NM (1999) Selective NMDA NR2B antagonists induce antinociception without motor dysfunction: correlation with restricted localisation of NR2B subunit in dorsal horn. Neuropharmacology 38:611-623.

Chaplan SR, Bach FW, Pogrel JW, Chung JM, Yaksh TL (1994) Quantitative assessment of tactile allodynia in the rat paw. J Neurosci Methods 53:55-63.

Fischer G, Mutel V, Trube G, Malherbe P, Kew JN, Mohacsi E, Heitz MP, Kemp JA (1997) Ro 25-6981, a highly potent and selective blocker of $\mathrm{N}$-methyl-D-aspartate receptors containing the NR2B subunit. Characterization in vitro. J Pharmacol Exp Ther 283:1285-1292.

Gill R, Alanine A, Bourson A, Buttelmann B, Fischer G, Heitz MP, Kew JN, Levet-Trafit B, Lorez HP, Malherbe P, Miss MT, Mutel V, Pinard E, Roever S, Schmitt M, Trube G, Wybrecht R, Wyler R, Kemp JA (2002) Pharmacological characterization of Ro 63-1908 (1-[2-(4-hydroxyphenoxy)-ethyl]-4-(4-methyl-benzyl)-piperidin-4-ol), a novel subtypeselective $N$-methyl-D-aspartate antagonist. J Pharmacol Exp Ther 302:940-948.

Guillaud L, Setou M, Hirokawa N (2003) KIF17 dynamics and regulation of NR2B trafficking in hippocampal neurons. J Neurosci 23:131-140.

Guo H, Huang LY (2001) Alteration in the voltage dependence of NMDA receptor channels in rat dorsal horn neurones following peripheral inflammation. J Physiol (Lond) 537:115-123.

Guo W, Zou S, Guan Y, Ikeda T, Tal M, Dubner R, Ren K (2002) Tyrosine phosphorylation of the NR2B subunit of the NMDA receptor in the spinal cord during the development and maintenance of inflammatory hyperalgesia. J Neurosci 22:6208-6217.

Guo W, Wei F, Zou S, Robbins MT, Sugiyo S, Ikeda T, Tu JC, Worley PF, Dubner R, Ren K (2004) Group I metabotropic glutamate receptor NMDA receptor coupling and signaling cascade mediate spinal dorsal horn NMDA receptor 2B tyrosine phosphorylation associated with inflammatory hyperalgesia. J Neurosci 24:9161-9173.

Higgins GA, Ballard TM, Huwyler J, Kemp JA, Gill R (2003) Evaluation of the NR2B-selective NMDA receptor antagonist Ro 63-1908 on rodent behaviour: evidence for an involvement of NR2B NMDA receptors in response inhibition. Neuropharmacology 44:324-341.

Hollmann M, Boulter J, Maron C, Heinemann S (1994) Molecular biology of glutamate receptors. Potentiation of $N$-methyl-D-aspartate receptor splice variants by zinc. Ren Physiol Biochem 17:182-183.

Huh KH, Wenthold RJ (1999) Turnover analysis of glutamate receptors identifies a rapidly degraded pool of the $N$-methyl-D-aspartate receptor subunit, NR1, in cultured cerebellar granule cells. J Biol Chem 274:151-157.

Hutchison WD, Davis KD, Lozano AM, Tasker RR, Dostrovsky JO (1999) Pain-related neurons in the human cingulate cortex. Nat Neurosci 2:403-405.

Ji RR, Befort K, Brenner GJ, Woolf CJ (2002) ERK MAP kinase activation in superficial spinal cord neurons induces prodynorphin and NK-1 upregulation and contributes to persistent inflammatory pain hypersensitivity. J Neurosci 22:478-485.

Kawakami R, Shinohara Y, Kato Y, Sugiyama H, Shigemoto R, Ito I (2003) Asymmetrical allocation of NMDA receptor epsilon2 subunits in hippocampal circuitry. Science 300:990-994.

Krapivinsky G, Krapivinsky L, Manasian Y, Ivanov A, Tyzio R, Pellegrino C, Ben-Ari Y, Clapham DE, Medina I (2003) The NMDA receptor is coupled to the ERK pathway by a direct interaction between NR2B and RasGRF1. Neuron 40:775-784.

Liauw J, Wang GD, Zhuo M (2003) NMDA receptors contribute to synaptic transmission in anterior cingulate cortex of adult mice. Sheng Li Xue Bao 55:373-380.

Liu L, Wong TP, Pozza MF, Lingenhoehl K, Wang Y, Sheng M, Auberson YP, Wang YT (2004) Role of NMDA receptor subtypes in governing the direction of hippocampal synaptic plasticity. Science 304:1021-1024.

Lynch DR, Shim SS, Seifert KM, Kurapathi S, Mutel V, Gallagher MJ, Guttmann RP (2001) Pharmacological characterization of interactions of RO 25-6981 with the NR2B (epsilon2) subunit. Eur J Pharmacol 416:185-195.

Malherbe P, Mutel V, Broger C, Perin-Dureau F, Kemp JA, Neyton J, Paoletti P, Kew JN (2003) Identification of critical residues in the amino terminal domain of the human NR2B subunit involved in the RO 25-6981 binding pocket. J Pharmacol Exp Ther 307:897-905.

Massey PV, Johnson BE, Moult PR, Auberson YP, Brown MW, Molnar E, Collingridge GL, Bashir ZI (2004) Differential roles of NR2A and NR2B-containing NMDA receptors in cortical long-term potentiation and long-term depression. J Neurosci 24:7821-7828.

Monyer H, Burnashev N, Laurie DJ, Sakmann B, Seeburg PH (1994) Developmental and regional expression in the rat brain and functional properties of four NMDA receptors. Neuron 12:529-540.

Mutel V, Buchy D, Klingelschmidt A, Messer J, Bleuel Z, Kemp JA, Richards JG (1998) In vitro binding properties in rat brain of [3H]Ro 25-6981, a potent and selective antagonist of NMDA receptors containing NR2B subunits. J Neurochem 70:2147-2155.

Nakanishi N, Axel R, Shneider NA (1992) Alternative splicing generates functionally distinct $N$-methyl-D-aspartate receptors. Proc Natl Acad Sci USA 89:8552-8556.

Philpot BD, Sekhar AK, Shouval HZ, Bear MF (2001a) Visual experience and deprivation bidirectionally modify the composition and function of NMDA receptors in visual cortex. Neuron 29:157-169.

Philpot BD, Weisberg MP, Ramos MS, Sawtell NB, Tang YP, Tsien JZ, Bear MF (2001b) Effect of transgenic overexpression of NR2B on NMDA receptor function and synaptic plasticity in visual cortex. Neuropharmacology 41:762-770.

Prybylowski K, Fu Z, Losi G, Hawkins LM, Luo J, Chang K, Wenthold RJ, Vicini S (2002) Relationship between availability of NMDA receptor subunits and their expression at the synapse. J Neurosci 22:8902-8910.

Quinlan EM, Lebel D, Brosh I, Barkai E (2004) A molecular mechanism for 
stabilization of learning-induced synaptic modifications. Neuron 41:185-192.

Ramon y Cajal S (1995) Cingulate cortex and cingulum. In: Histology of the nervous system of man and vertebrates, pp 658-676. New York: Oxford UP.

Roche KW, Standley S, McCallum J, Dune Ly C, Ehlers MD, Wenthold RJ (2001) Molecular determinants of NMDA receptor internalization. Nat Neurosci 4:794-802.

Rosenblum K, Berman DE, Hazvi S, Lamprecht R, Dudai Y (1997) NMDA receptor and the tyrosine phosphorylation of its $2 \mathrm{~B}$ subunit in taste learning in the rat insular cortex. J Neurosci 17:5129-5135.

Sawtell NB, Frenkel MY, Philpot BD, Nakazawa K, Tonegawa S, Bear MF (2003) NMDA receptor-dependent ocular dominance plasticity in adult visual cortex. Neuron 38:977-985.

Setou M, Nakagawa T, Seog DH, Hirokawa N (2000) Kinesin superfamily motor protein KIF17 and mLin-10 in NMDA receptor-containing vesicle transport. Science 288:1796-1802.

Sheng M, Cummings J, Roldan LA, Jan YN, Jan LY (1994) Changing subunit composition of heteromeric NMDA receptors during development of rat cortex. Nature 368:144-147.

Sikes RW, Vogt BA (1992) Nociceptive neurons in area 24 of rabbit cingulate cortex. J Neurophysiol 68:1720-1732.

Tang YP, Shimizu E, Dube GR, Rampon C, Kerchner GA, Zhuo M, Liu G, Tsien JZ (1999) Genetic enhancement of learning and memory in mice. Nature 401:63-69.

Tao YX, Rumbaugh G, Wang GD, Petralia RS, Zhao C, Kauer FW, Tao F, Zhuo M, Wenthold RJ, Raja SN, Huganir RL, Bredt DS, Johns RA (2003) Impaired NMDA receptor-mediated postsynaptic function and blunted NMDA receptor-dependent persistent pain in mice lacking postsynaptic density-93 protein. J Neurosci 23:6703-6712.

Tongiorgi E, Ferrero F, Cattaneo A, Domenici L (2003) Dark-rearing decreases NR2A N-methyl-D-aspartate receptor subunit in all visual cortical layers. Neuroscience 119:1013-1022.

Traub RD, Whittington MA, Stanford IM, Jefferys JG (1996) A mechanism for generation of long-range synchronous fast oscillations in the cortex. Nature 383:621-624.

Wei F, Zhuo M (2001) Potentiation of sensory responses in the anterior cingulate cortex following digit amputation in the anaesthetised rat. J Physiol (Lond) 532:823-833.

Wei F, Li P, Zhuo M (1999) Loss of synaptic depression in mammalian anterior cingulate cortex after amputation. J Neurosci 19:9346-9354.

Wei F, Xu ZC, Qu Z, Milbrandt J, Zhuo M (2000) Role of EGR1 in hippocampal synaptic enhancement induced by tetanic stimulation and amputation. J Cell Biol 149:1325-1334.

Wei F, Wang GD, Kerchner GA, Kim SJ, Xu HM, Chen ZF, Zhuo M (2001) Genetic enhancement of inflammatory pain by forebrain NR2B overexpression. Nat Neurosci 4:164-169.

Wei F, Qiu CS, Kim SJ, Muglia L, Maas JW, Pineda VV, Xu HM, Chen ZF, Storm DR, Muglia LJ, Zhuo M (2002) Genetic elimination of behavioral sensitization in mice lacking calmodulin-stimulated adenylyl cyclases. Neuron 36:713-726.

Wenthold RJ, Sans N, Standley S, Prybylowski K, Petralia RS (2003) Early events in the trafficking of $N$-methyl-D-aspartate (NMDA) receptors. Biochem Soc Trans 31:885-888.

Wong RW, Setou M, Teng J, Takei Y, Hirokawa N (2002) Overexpression of motor protein KIF17 enhances spatial and working memory in transgenic mice. Proc Natl Acad Sci USA 99:14500-14505.

Zhao MG, Toyoda H, Lee YS, Wu LJ, Ko SW, Zhang XH, Jia Y, Shum F, Xu H, Li BM, Kaang BK, Zhuo M (2005) Roles of NMDA NR2B subtype receptor in prefrontal long-term potentiation and contextual fear memory. Neuron 47:859-872.

Zhuo M (2002) Glutamate receptors and persistent pain: targeting forebrain NR2B subunits. Drug Discov Today 7:259-267.

Zinebi F, Xie J, Liu J, Russell RT, Gallagher JP, McKernan MG, ShinnickGallagher P (2003) NMDA currents and receptor protein are downregulated in the amygdala during maintenance of fear memory. J Neurosci 23:10283-10291. 